\title{
CONF-950952-1/2 \\ DOE IER/81364--6 \\ SULFIDATION AND REDUCTION OF \\ ZINC TITANATE AND ZINC OXIDE SORBENTS \\ FOR INJECTION IN GASIFIER EXIT DUCTS
}

\author{
K. ISHIKAWA*, C. KRUEGER, M. FLYTZANI-STEPHANOPOULOS** \\ Dept. of Chemical Engineering, Tufts University \\ 4 Colby St. Medford, MA 02155, U.S.A. \\ W. JI, R. J. HIGGINS, B. A. BISHOP, R. L. GOLDSMITH \\ CeraMem Corporation \\ 12 Clematis Ave. Waltham, MA 02154, U.S.A.
}

\begin{abstract}
The sulfidation reaction kinetics of fine particles of zinc titanate and zinc oxide with $\mathrm{H}_{2} \mathrm{~S}$ were studied in order to test the potential of the sorbent injection hot-gas desulfurization process. Fine sorbent particles with diameter between 0.3 and $60 \mu \mathrm{m}$ were sulfided with $\mathrm{H}_{2} \mathrm{~S}$ and/or reduced with $\mathrm{H}_{2}$ in a laminar flow reactor over the temperature range of $500-900^{\circ} \mathrm{C}$. Sulfidation/reduction conversion was compared for different particle sizes and sorbents with various porosities and atomic ratios of $\mathrm{Zn}$ and Ti. In reduction of $\mathrm{ZnO}$ with $\mathrm{H}_{2}$ and without $\mathrm{H}_{2} \mathrm{~S}$, significant amount of $\mathrm{Zn}$ was formed and vaporized, while the presence of $\mathrm{H}_{2} \mathrm{~S}$ suppressed elemental $\mathrm{Zn}$ formation. This suggests that $\mathrm{H}_{2} \mathrm{~S}$ may suppress the surface reduction of $\mathrm{ZnO}$ and/or gaseous $\mathrm{Zn}$ may react with $\mathrm{H}_{2} \mathrm{~S}$ homogeneously and form fine particles of $\mathrm{ZnS}$. Formation and vaporization of elemental $\mathrm{Zn}$ from zinc titanate sorbents was slower than from zinc oxide with and without $\mathrm{H}_{2} \mathrm{~S}$.

\section{INTRODUCTION}

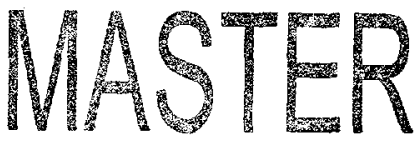

An advanced gas cleanup process, i.e. hot gas desulfurization and dust removal, is required for the high efficiency and low emission levels of the integrated coal gasification combined-cycle power generation (IGCC) and the gasification-molten carbonate fuel cell (MCFC) system. Among several metal oxides which react with $\mathrm{H}_{2} \mathrm{~S}$ to form solid metal sulfides, $\mathrm{ZnO}$ has been studied extensively as a desulfurization sorbent of $\mathrm{H}_{2} \mathrm{~S}$. Though $\mathrm{ZnO}$ is a potential candidate as a sorbent material with quite favorable thermodynamic equilibrium of sulfidation with $\mathrm{H}_{2} \mathrm{~S}$, it has a major problem, namely, formation and vaporization of elemental $\mathrm{Zn}$ by reduction reaction with $\mathrm{H}_{2}$ and $\mathrm{CO}$ in the coal derived gas. More recently, mixed oxide sorbents, particularly $\mathrm{Zn}-\mathrm{Ti}-\mathrm{O}$, have been considered as more promising sorbents combining high desulfurization performance, easiness of regeneration, and high stability.

The reaction schemes with $\mathrm{ZnO}$ and $\mathrm{Zn}$-Ti-O sorbents are as follows;

\footnotetext{
** To whom correspondence should be addressed.

* Present address: KAWASAKI HEAVY INDUSTRIES, LTD. Akashi Technical Institute 1-1 Kawasaki-cho, Akashi 673 Japan 


\section{DISCLAIMER}

This report was prepared as an account of work sponsored by an agency of the United States Government. Neither the United States Government nor any agency thereof, nor any of their employees, make any warranty, express or implied, or assumes any legal liability or responsibility for the accuracy, completeness, or usefulness of any information, apparatus, product, or process disclosed, or represents that its use would not infringe privately owned rights. Reference herein to any specific commercial product, process, or service by trade name, trademark, manufacturer, or otherwise does not necessarily constitute or imply its endorsement, recommendation, or favoring by the United States Government or any agency thereof. The views and opinions of authors expressed herein do not necessarily state or reflect those of the United States Government or any agency thereof. 


\section{DISCLAMMER}

Portions of this document may be illegible in electronic image products. Images are produced from the best available original document. 


$$
\begin{aligned}
& \mathrm{H} 2 \mathrm{~S} \text { Uptake ; } \mathrm{ZnO}+\mathrm{H}_{2} \mathrm{~S} \quad \rightarrow \mathrm{ZnS}+\mathrm{H}_{2} \mathrm{O} \\
& \mathrm{Znx} \text { Tiy } \mathrm{Ox}+\mathrm{yO}_{2}+\mathrm{xH}_{2} \mathrm{~S} \quad \rightarrow \mathrm{xZnS}+\mathrm{yTiO}_{2}+\mathrm{xH}_{2} \mathrm{O} \\
& \text { Regeneration; } 2 \mathrm{ZnS}+3 \mathrm{O} 2 \\
& \rightarrow 2 \mathrm{ZnO}+2 \mathrm{SO}_{2} \\
& \mathrm{xZnS}+\mathrm{yTiO}_{2}+(3 \mathrm{x} / 2) \mathrm{O}_{2} \quad \rightarrow \mathrm{Zn}_{\mathrm{TTiyO}}+\mathrm{yO}_{2}+\mathrm{xSO} 2 \\
& \text { Reduction ; } \mathrm{ZnO}+\mathrm{H}_{2} \text { (or CO) } \rightarrow \mathrm{Zn}+\mathrm{H}_{2} \mathrm{O} \text { (or } \mathrm{CO}_{2} \text { ) } \\
& \mathrm{Znx} \text { TiyOx+y- }+\mathrm{xH}_{2}(\text { or } \mathrm{xCO})->\mathrm{xZn}+\mathrm{yTiO}_{2}+\mathrm{xH}_{2} \mathrm{O}(\text { or } \mathrm{xCO} \text { ) }
\end{aligned}
$$

However, loss of $\mathrm{Zn}$ by reduction, long-term stability, and mechanical durability of the material are still problems in any type of reactor, such as moving bed (granular sorbent), fluidized bed (powdered sorbent), and fixed bed (particle or monolith).

One possible way to avoid all the problems with $\mathrm{H}_{2} \mathrm{~S}$ sorbents mentioned above is the sorbent injection process. Fig. 1 shows the process schematic of the sorbent injection process. In this process, fine powder of the sorbent is injected into the reaction section, actually a gas pipe, and entrained with the coal derived gas. The sorbent is then captured by a porous ceramic micro filter, on which desulfurization reaction still takes place. The filter is backflushed intermittently, and the sorbent removed from the filter is entrained and regenerated by regeneration (oxidizing) gas and sent to a lock hopper prior to re-injection.

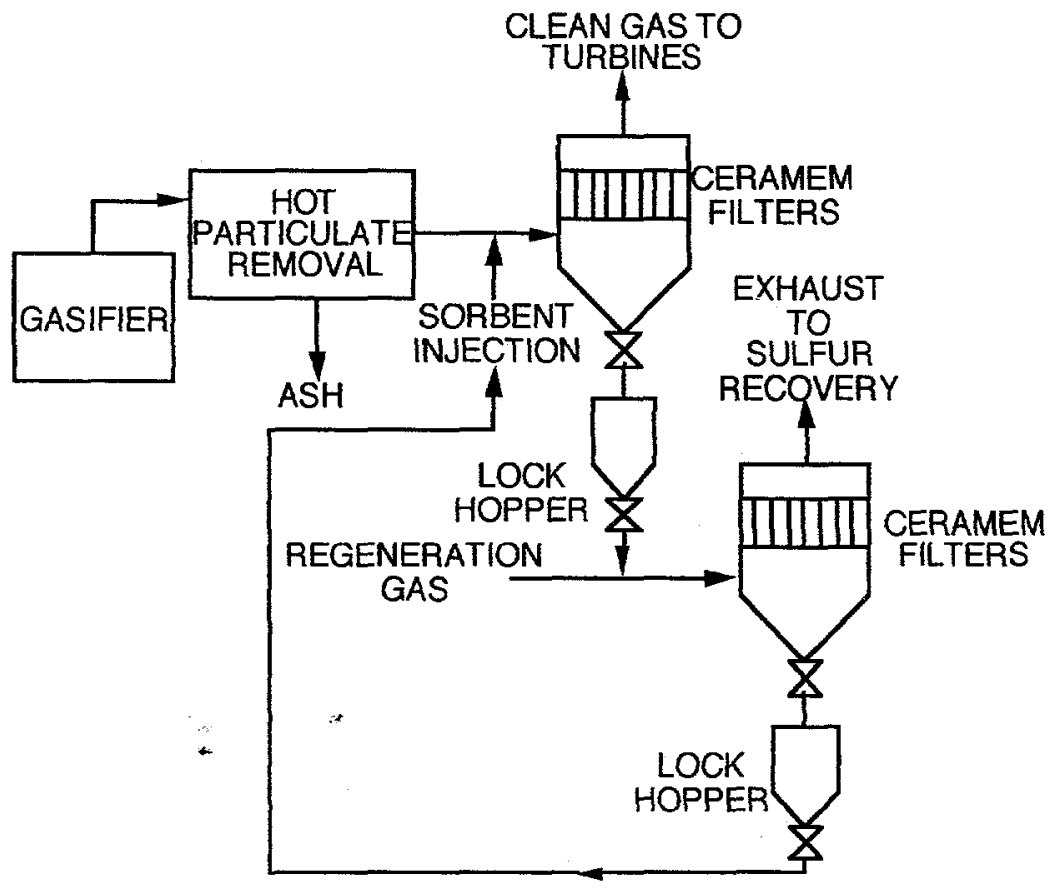

Fig. 1 A process schematic of the sorbent injection process (CeraMem Corporation)

Sorbent injection process in conjunction with a porous ceramic micro filter which can collect particles as small as less than 1 micron in diameter may be a solution to many of the problems with Zn-based sorbent because 1) the sorbent injection process can collect fine zinc sulfide formed with gaseous reaction of $\mathrm{Zn}$ vapor and $\mathrm{H}_{2} \mathrm{~S}$, thus avoiding the loss of $\mathrm{Zn} ; 2$ ) fine powder encounters no attrition problem in duct; and 3) very fine particle size of the sorbent and the possible pathway of gaseous reaction between $\mathrm{H}_{2} \mathrm{~S}$ and $\mathrm{Zn}$ vapor may enhance the total desulfurization reactivity as suggested in a previous study [1]. Fig. 2 shows an anticipated reaction scheme which includes two reaction pathways, i.e. a solid-gas reaction between $\mathrm{ZnO}$ and $\mathrm{H}_{2} \mathrm{~S}$, and a gas phase reaction between $\mathrm{Zn}$ vapor and $\mathrm{H}_{2} \mathrm{~S}$. 


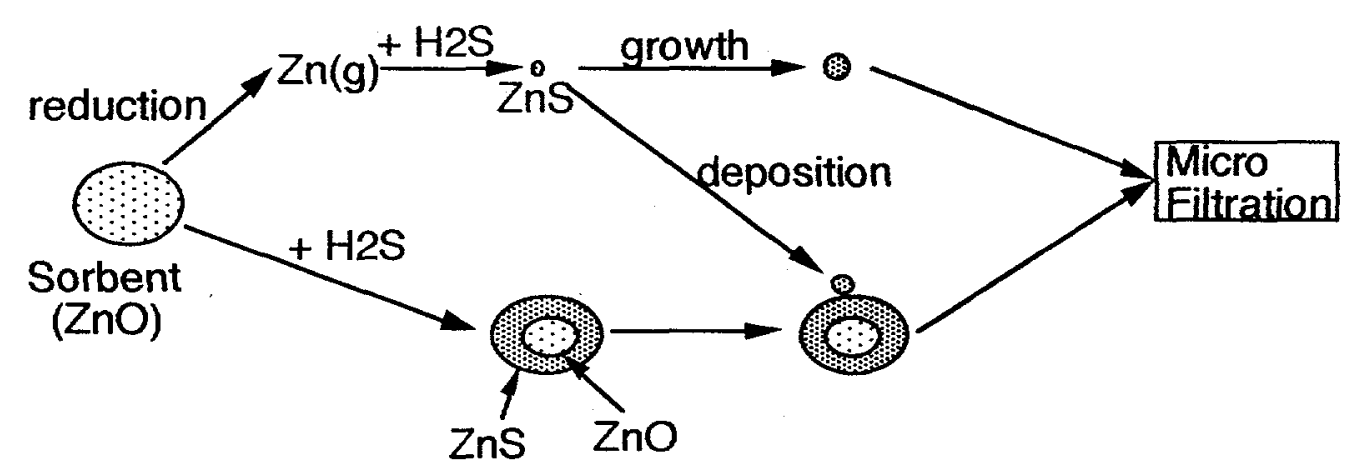

Fig. 2 An anticipated reaction scheme of a single sorbent particle

\section{EXPERIMENTAL METHODS}

\section{Preparation of Sorbents}

In the sorbent injection process, very fine powder of sorbent can be used and the micro structure of the sorbent material is expected not to affect much its reactivity. One of the objectives of this study is to compare several kinds of sorbents in terms of reactivity and to determine if low surface area material can be used. Therefore, in this study, a $\mathrm{ZnO}$ prepared at Massachusetts Institute of Technology by the complexation method[1] was used as the standard sorbent and compared with commercial materials, i.e. $\mathrm{ZnO}$ obtained from Johnson Matthey and $\mathrm{ZnTiO}_{3}$ from Pfaltz and Bauer. As a Zn-Ti-O sorbent, and L-3140 sorbent of United Catalysts Inc.

\section{Physical and Chemical Analysis of Sorbents}

(i) Physical analysis. The pore size distributions and the surface areas of the sorbents were measured using a Micromeritics Autopore 9200 Mercury Porosimeter and a Micromeritics Flow Sorb 2300 BET apparatus, respectively.

(ii) Chemical analysis. Sulfidation conversion of the reacted $\mathrm{ZnO}$ and $\mathrm{Zn}-\mathrm{Ti}-\mathrm{O}$ sorbents in the drop-tube furnace assembly were measured using a Cahn System $113-X$ thermogravimetric analyzer (TGA). This analysis was based on the weight change of the sorbents upon regeneration reaction at $750^{\circ} \mathrm{C}$ in 6 vol\% $\mathrm{O}_{2}$ in $\mathrm{N}_{2}$. The effect of elemental $\mathrm{Zn}$ formed by reduction with $\mathrm{H}_{2}$ in the reactant gas and adsorbed materials such as $\mathrm{H}_{2} \mathrm{~S}$ or $\mathrm{H}_{2} \mathrm{O}$ were subtracted by heating the sample to stable weight at $750^{\circ} \mathrm{C}$ in $\mathrm{N}_{2}$ before introducing $\mathrm{O}_{2}$.

\section{Drop-Tube Furnace Experiments}

Fig. 3 shows the flow schematic of the drop-tube test facility. The reactor is a 1.5 inch I.D. quartz tube and the feeder probe through which the sorbent is entrained by carrier gas is a 1/8 inch O.D. quartz tube. The collection probe is made of stainless steel and water-cooled. The collection probe has a porous inner wall through which $\mathrm{N} 2$ gas was emitted into the reacted gas for quenching.

The reactant gas, a simulated coal gasifier-exit gas, comprises $\mathrm{H}_{2} \mathrm{~S}, \mathrm{H}_{2}, \mathrm{CO}_{2}$, and N2. Other components such as $\mathrm{CO}, \mathrm{H}_{2} \mathrm{O}$, and trace of $\mathrm{COS}$ are omitted from the present experiments. Each gas component was fed from a gas cylinder and the flow rate was controlled by a mass flow controller. Sorbent particles were previously classified in a known size range and fed into a drop-tube down-flow reactor at a constant rate through a particle feeder. $\mathrm{CO}_{2}$ or $\mathrm{He}$ was mainly used as the carrier 


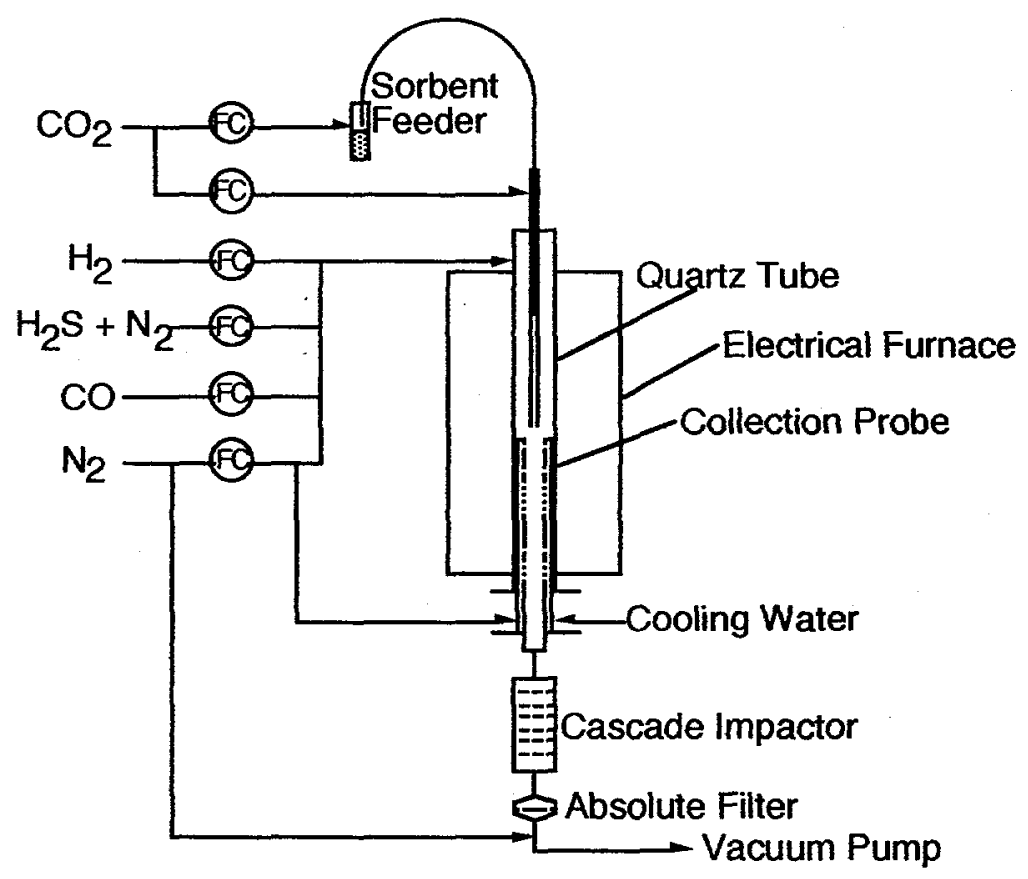

Fig. 3 The flow schematic of the drop-tube test facility

gas of the sorbent. The sorbent contacted the reactant gas for a certain distance, i.e. a certain contact time. In addition to the reactant gas, $\mathrm{N} 2$ was fed to the collection probe for quenching the reacted gas. The reacted gas and N2 from the collection probe were then led to a cascade impactor, University of Washington Mark 3 type, in which sorbent particles contained in the gas flow were classified according to the particle size into seven stages and a final paper filter.

By using a drop-tube reactor in conjunction with a cascade impactor, sulfidation conversion of different size sorbent particles can be measured separately because the cascade impactor size-classifies the particles in the reacted gas flow. Furthermore, the change of size distribution of the sorbent after the reaction could provide information on the reduction of $\mathrm{ZnO}$ and vaporization of $\mathrm{Zn}$.

\section{TABLE 1}

Reaction conditions for the drop-tube furnace experiments

\begin{tabular}{ll}
\hline Sorbent Size: & $0.3-0.6 \mu \mathrm{m}$ (pneumatic sieving) \\
& $30-63 \mu \mathrm{m}$ (dry sieving) \\
Temperature : & $620-850^{\circ} \mathrm{C}$ \\
Reaction Zone Length: & $5-30 \mathrm{~cm}$ \\
Bulk Flow Velocity: & $5-10 \mathrm{~cm} / \mathrm{s}$ (Reactant gas flow) \\
Jet Flow Velocity: & $48-97 \mathrm{~cm} / \mathrm{s}$ (The flow containing the sorbent) \\
Molar Composition: & $\mathrm{H} 2 \mathrm{~S} ; \mathrm{O}($ reduction), $0.4-2.0 \%$ \\
of reactant gas & $\mathrm{H} 2 ; 0-66 \%, \mathrm{CO} 2 ;-18 \%$ \\
Carrier (Jet) Gas : & $\mathrm{He}, \mathrm{CO} 2,6 \% \mathrm{H} 2 \mathrm{~S}-\mathrm{N} 2, \mathrm{H} 2$ \\
\hline
\end{tabular}

\section{RESULTS}

Reduction/sulfidation of $\mathrm{ZnO}$ sorbents

Fig. 4(a) shows size distributions of ZnO-2 sorbent measured with the cascade impactor after reduction/sulfidation reaction at various conditions. It is clear that the 
powder over $10 \mu \mathrm{m}$ size decreased while the 1.5-5 $\mu \mathrm{m}$ size range increased after reduction. This suggests that formation and vaporization of elemental zinc take place in reduction. With $\mathrm{H}_{2} \mathrm{~S}$ in the reactant gas, however, the change of size distribution is small or negligible except at $850^{\circ} \mathrm{C}$.

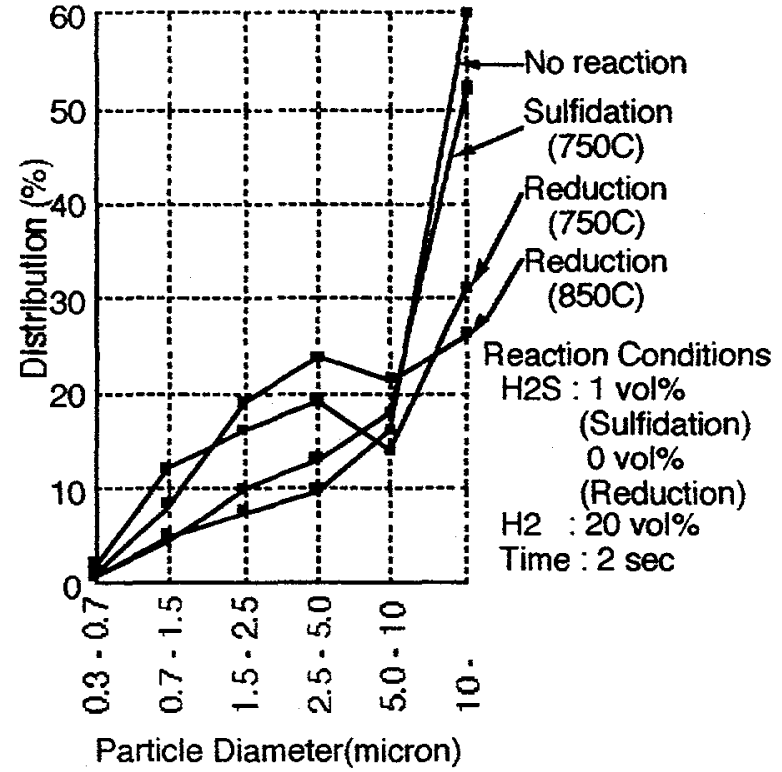

(a) Size distribution of sulfided/reduced $\mathrm{ZnO}-2$ sorbent

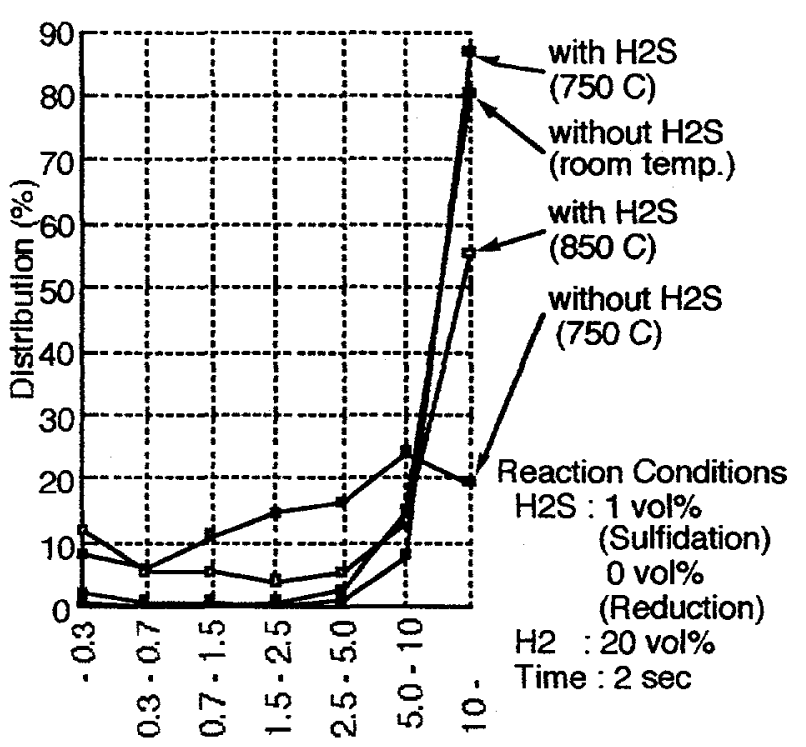

Particle Diameter (micron)

(b) Size distribution of sulfided/reduced metallic $\mathrm{Zn}$

Fig. 4 Size distributions of ZnO-2 sorbent and metallic $\mathrm{Zn}$ powder after reduction/sulfidation reaction

In the sulfidation conversion measurement by in the TGA, no weight reduction associated with the vaporization of elemental $\mathrm{Zn}$ during the heating in $\mathrm{N} 2$ was observed. This indicates that if any elemental $\mathrm{Zn}$ was deposited on the particles, it was quickly either sulfided by $\mathrm{H}_{2} \mathrm{~S}$ or oxidized by product water. This result coincides with a previous study that $\mathrm{H}_{2} \mathrm{~S}$ suppressed the reduction of $\mathrm{ZnO}$ [2]. The mechanism of decreased fines formation with $\mathrm{H}_{2} \mathrm{~S}$ may be the suppression of the reduction reaction itself or immediate sulfidation of $\mathrm{Zn}$ vapor formed. In order to examine the latter effect of $\mathrm{H}_{2} \mathrm{~S}$, separately, fine powder of metallic $\mathrm{Zn}$ was fed into the reactor with and without $\mathrm{H}_{2} \mathrm{~S}$ and its particle size distribution at the outlet of the reactor was measured. Fig. 4(b) shows the results a)without $\mathrm{H}_{2} \mathrm{~S}$ at room temperature (i.e. no reaction or vaporization), b)without $\mathrm{H}_{2} \mathrm{~S}$ at $750^{\circ} \mathrm{C}$ (i.e. no reaction but vaporization), c) with $1 \mathrm{vol} \% \mathrm{H}_{2} \mathrm{~S}$ at $750^{\circ} \mathrm{C}$, d) with $1 \mathrm{vol} \% \mathrm{H}_{2} \mathrm{~S}$ at $850^{\circ} \mathrm{C}$. This result shows that the existence of no more than 1 vol\% of $\mathrm{H}_{2} \mathrm{~S}$ inhibited the vaporization of $\mathrm{Zn}$ almost completely at $750^{\circ} \mathrm{C}$. At $850^{\circ} \mathrm{C}$, however, the vaporization of $\mathrm{Zn}$ was so rapid that some of the vaporized $\mathrm{Zn}$ escapes the original particle surface to form fine powder of $\mathrm{ZnS}$ by gaseous sulfidation with $\mathrm{H}_{2} \mathrm{~S}$.

Judging from the fact that the vaporization of metallic $\mathrm{Zn}$ was effectively suppressed by $\mathrm{H}_{2} \mathrm{~S}$ even with metallic zinc powder as the starting material, $\mathrm{H}_{2} \mathrm{~S}$ seems to suppress mainly the vaporization by immediate formation of $\mathrm{ZnS}$, not the reduction reaction itself.

Assuming that the surface reaction is the rate limiting step and that other factors, such as gas composition gradient and particle velocity, are not influenced by temperature, the activation energy was calculated as $7.1-10.9 \mathrm{kcal} / \mathrm{mol}$, slightly different depending on particle size. The particle size dependence of the sulfidation 
conversion was found to correspond to the particle surface area. This is because the conversion in almost all the experiments was no higher than $15 \%$. In these tests, we could not exceed conversions higher than $15 \%$.

\section{Comparison of Sorbents}

Table 2 shows the sulfidation conversions of $\mathrm{ZnO}-2(\mathrm{MIT}), \mathrm{ZnO}$ (Johnson Matthey), $\mathrm{ZnTiO}$ (Pfaltz \& Bauer), and L-3140(UCl) sorbents at the same reaction conditions.

The difference between two types of $\mathrm{ZnO}$ mainly depends on the surface area because the surface reaction rates per surface area for are almost the same. The difference between $\mathrm{ZnO}-2$ and zinc titanate depends on both the surface area and the lower reactivity of titanate[3]. The original particle size of L-3140 had little effect on sulfidation conversion or even on the observed size distribution in the cascade impactor, apparently due to agglomeration of fine particles.

\section{TABLE 2}

Sulfidation Conversions of $\mathrm{ZnO}$ and Zinc Titanate Sorbents

\begin{tabular}{llccc}
\hline Sorbent & $\begin{array}{l}\text { Initial Particle } \\
\text { Size }(\mu \mathrm{m})\end{array}$ & Carrier Gas & $\begin{array}{c}\text { Conversion } \\
(\%)\end{array}$ & $\begin{array}{c}\text { Surface Reaction } \\
\text { Rate }(\mathrm{mol} / \mathrm{cm} 2 \mathrm{~s})\end{array}$ \\
\hline ZnO-2(MIT) & $40-52$ & $\mathrm{H} 2$ & 5.2 & $1.60 \mathrm{E}-8$ \\
& & $\mathrm{He}$ & 2.1 & $0.65 \mathrm{E}-8$ \\
ZnO (Johnson Matthey) & $40-52$ & $\mathrm{H} 2$ & 0.6 & $1.84 \mathrm{E}-8$ \\
ZnTiO3 (Pfaltz \& Bauer) & $40-52$ & $\mathrm{H} 2$ & 1.6 & $0.70 \mathrm{E}-8$ \\
L-3140(UCl) & $40-52$ & $\mathrm{He}$ & 6.9 & $2.37 \mathrm{E}-7$ \\
L-3140(UCl) & $2.8-5.9$ & $\mathrm{He}$ & 5.6 & $1.15 \mathrm{E}-8$ \\
\hline
\end{tabular}

Reaction conditions : $750^{\circ} \mathrm{C}, \mathrm{H}_{2} \mathrm{~S} 1.0 \mathrm{vol} \%, \mathrm{H}_{2} 20 \mathrm{vol} \%$, Contact time $=2 \mathrm{sec}$ Diameter of analysed particle : 5-10 $\mu \mathrm{m}$

at reaction temperature

\section{CONCLUSIONS}

1) At $750^{\circ} \mathrm{C}$ or lower temperature, $\mathrm{H}_{2} \mathrm{~S}$ was found to almost completely inhibit the size decrease of sorbent particles caused by vaporization of elemental $\mathrm{Zn}$ formed by reduction of $\mathrm{ZnO}$ with $\mathrm{H}_{2}$. This effect seems to be mainly suppression of zinc vaporization, not the reduction reaction.

2) At $850^{\circ} \mathrm{C}$, fine particles less than $0.3 \mu \mathrm{m}$ in diameter were formed even in the presence of $\mathrm{H}_{2} \mathrm{~S}$. These fine particles were found to be $\mathrm{ZnS}$ formed by the reaction of vaporized zinc and $\mathrm{H}_{2} \mathrm{~S}$ and would be possibly captured by micro filtration. Therefore, at this temperature, vaporization of zinc and formation of fine particles aids the conversion of the sorbent.

3) $\mathrm{ZnO}$ sorbent has high potential for the sorbent injection hot gas cleanup process because $\mathrm{ZnO}$ has higher sulfur loading capacity and its drawbacks can be covered by the process.

\section{REFERENCES}

1. Lew, S. Ph.D Thesis, Massachusetts Institute of Technology (1990)

2. Lew, S., Sarofim, A.F., Flytzani-Stephanopoulos, M. AlChE J. Vol.38(8), 1161 (1992)

3. Lew, S., Sarofim, A.F., Flytzani-Stephanopoulos, M. Ind.Eng.Chem.Res. Vol.31 (8), $1890(1992)$ 